\title{
Funding as a Determinant of Secondary Education Effectiveness in Cross River State, Nigeria from 2006-2016
}

\author{
Akeke, Mercy N. G.Ph.D \\ Department of Vocational Education \\ Faculty of Education \\ University of Calabar \\ Nigeria
}

\begin{abstract}
This study investigated funding as a determinant of secondary education effectiveness in Cross River State, Nigeria from 2006-2016. To achieve the study, three research questions were raised and two hypotheses formulated to guide the study. Ex-post facto research design was adopted. The population is 246 Secondary Schools in the study area. However,principals were used to answer the research questions and questionnaires. Census sampling technique was used since the population was manageable. The instrument used for this study was a questionnaire titled "Secondary education funding effectiveness appraisal inventory" (SEFEAI)and checklists known as "Qualitative output trend" (QOT) were used to elicit information from the respondents. The questionnaire was validated by two experts in Measurement and Evaluation as well as Educational Administration and Planning. The reliability value ranging between 0.70 and 0.95 was established using Cronbach alpha method. The statistical tool used for data analysis was two way analysis of variance and descriptive statistics. The result of the analysis showed that funding of secondary education through parent teachers association and community contribution significantly influence Secondary Education effectiveness in Cross River State. It was recommended among others that communities should give maximum financial support to secondary education because investment in education is building the future economy of the nation as well as ensuring better output.
\end{abstract}

\section{Introduction}

Education in Nigeria prior to 2002 was mostly seen as the exclusive responsibility of the government, after which, there was a de-regulation of education in the country. The three tiers of government (federal, state and local) are the bodies responsible for the funding of educational services in Nigeria through grants. The purpose of this grant is to carter for recurrent and capital expenditures to ensure school effectiveness, secondary education inclusive. Secondary education refers to that level of education in Nigeria which lasts for six years and given in two stages: a junior secondary and senior secondary school; each shall be of three years duration (Federal Republic of Nigeria, 2014).

The broad goals of secondary education are to prepare the individual for useful living within the society and higher education (Federal Republic of Nigeria, 2014). However, it has been observed with dismay as well as reported that Cross River State performs poorly in West African Examination Council in the past years ranking from $20^{\text {th }}$ position against other states like Abia, Anambra and Edo states that maintains the first five positions in the ranking (Eguridu, 2014). If this situation is not improved, may cause the state to be educationally backward in the near future. The poor performance could be viewed as ineffectiveness of secondary education in Cross River State.

Secondary education effectiveness may be seen as the ability to provide resources needed to enhance teaching and learning in a school and utilizing them maximally for the purpose of goal attainment. These resources include human, material, physical and financial resources. When the resources are adequately provided and harmoniously utilized, they produce expected results in secondary education. The results manifest in the outputs of the schools (leavers). Secondary education effectiveness is seen as the ability of school administrator (principal) to utilize the available fund in the management of school activities to attain pre-determined goals (Okon, 2017). Adequate provision of learning materials, conducive learning environment, proper motivation and training of teachers to ensure content mastery and impart students properly for attainment of school goals and objective is termed school effectiveness. 
An analysis byOweh (2013) for 2000, 2010, 2011 and 2013 portray Nigerian budgetary allocation to education as $16.17 \%, 4.08 \%, 10.24 \%$ and $8 \%$ respectively. These show funding below the $26 \%$ stipulated by United Nations Education Scientific and Cultural Organization for the funding of education in developing countries which Nigeria is one. This challenge of inadequate funding makes it impossible for Principals to provide the needed resources to enhance teaching and learning. In view of this, funds from Parent-teachers Association (PTA) and community contributions may go a long way to help in the provision of materials needed for the effectiveness of secondary education in the state. PTA contributions are monies gotten through levies on parents and teachers which can be used in supporting the school funds. Community contribution is a situation where the host community contribute in kind or cash for the support of schools in their community to show support towards the education of their children.

\section{Literature Review}

The cost of education is constantly increasing due to inflation and increase in the number of beneficiaries of education. As a result of this, government cannot properly fund the process. In a study conducted by Jimennez and Paques (1996) on the topic, "Funding of public primary schools for improved performance". Four research questions were posed, the findings of the study showed that schools which rely more on local sources, such as contributions from local school board, municipal government, parent-teachers association (PTA) and other sources are more efficient. They have lower cost, holding constant in enrollment and quality and only $1 \%$ increase in the share of financing will lead to a decline in total costs of $0.135 \%$. Secondary schools can borrow a leave from this and source for alternative sources of funding since the issue of funding education is a general issue in Cross River State. In addition to this, Bassey, Akuegwu and Udida(2007) referencing Nigerian Report (2006) asserted that president Obasanjo had called on utility administrators to enhance their internal revenue generation as well as seek funds from private organizations, adding that the days of total or even near total reliance on governments funding were over.

It could be that the days of total or near total reliance on government funding is over, then school administrators should sit up and look inwards to identify possible avenues through which funds can be raised to supplement whatever the government will make available to them. The following were identified as the possible ways of generating funds internally; weekend residential library services, car fee charge, endowment earning, consultancy services, setting up/reactivation of farm, mounting of evening school or classes, organization of workshops, seminars and conferences, hiring of school facilities and establishment of nursery primary school. These are good possible ways of raising fund internally to support the day to day expenditures of the school.

In agreement with the above study, Bartle (2013) conducted a study on influence of parent teacher association on school administration and two research questions were posed. The study population was made up of 214 secondary schools in the study area. Census was used since the schools were few and it was found out that PTA contributes immensely to the physical facilities in the schools as well as in monitoring teachers' relationship with students. This agrees with the assertion of Eze 2002, Odo 2007 in Okenwa and Elechi (2015) that government alone appears unable to meet up with the financial demands of schools which make the participation of the community and PTA in the school funding impressive.

It must be noted that some communities raise funds, equip schools and hand over to the government but most times, do not monitor the utilization which results to misappropriation (Ibekwe, 2012). Adding to the above state, Onyerke, (2012) opined that it is pertinent to note that community and parents play a role in the provision for building and maintenance, transport to school, food, uniform and other learning materials which is usually significant at the basic level and cannot be qualified In a study carried out by EmenaloandCamilus (2013) on appraisal of community involvement in secondary schools' development in Okigwe education zone of Imo state, a research hypothesis was formulated that there is no significant difference between the mean scores of principals and board of governors of senior secondary schools in Okigwe education zone in community involvement in the funding of senior secondary schools at 0.05 level of significance. The population of the study was comprised of seventy-eight (78) secondary school principals and seventy-eight (78) bursars. Boarding governors and census was adopted. The statistical tool used for data analysis was Z-test and mean score of 2.50 and above was used. The findings showed $\mathrm{Z}$ calculations of 0.385 and the critical of 1.96 with 98 degree of freedom at 0.05 level of significance. Therefore, the null hypothesis was accepted that there is community involvement in funding secondary schools in Okigwe zone. 
This agrees with Oloko and Nwosu (2016) who conducted a study on "Assessment of alternative fund strategies for the implementation of universal basic education programme". One of the hypotheses formulated is that there is no significant difference between the mean score of male and female principals in the host communities' contributions as alternative funding strategies for the implementation of universal basic education programme in public secondary schools in Rivers State. The design adopted was a descriptive survey. A sample of 75 male and 49 female principals representing 50\% of the population. Man score (x), standard deviation (SD), rank order, decision rule and z-test were statistical tool used for data analysis which was tested at 0.05 level of significance. The finding shows that the host communities' contributions were in areas of acquisition of land and support for school projects.

Adding to this is a study carried by Anyawu, Iheanacho and Anowe (2016) on forms and challenges of community participation in funding rural primary schools in Imo State, hypothesis was formulated that there is no significant difference in the views of the male and female respondents with regards to the forms of community participation in funding rural primary education. T-test and ANOVA were used to test the hypothesis. A total of 3000 respondents were served as the population of the study which included 1,310 youths, 630 elders and 1060 administrative staff. The funding shows that there were up to 19 forms of community participation in funding rural education in Imo State. They added that communities have a role to play in funding secondary education. This could be in the form of donation of teaching and learning materials awards of scholarship to indigent students, donating sports equipment, provision of financial rewards to outstanding students, provision of building materials, payments for direct labour and donation of lands.

\section{Statement of Problem}

Inadequate funding hampers the school administrator's ability to perform repairs and purchase of modern instructional materials to meet up with the challenging school needs in recent years and to ensure effectiveness. Modern equipment that should be used in the training of these children to make them acquire skills capable of making them compete favourably with their pairs all over the world cannot be provided. The deplorable state of secondary schools and poor performance of secondary school students in their final year examinations (West African examination council) may be evidence of ineffectiveness in teaching and learning accruing from inadequate funding and utilization.

The ineffectiveness in our secondary education is made manifest in the poor products. It is quite disheartening that most secondary school leavers cannot write properly while some cannot read fluently. The observed ineffectiveness of the education system may be accounted for by several factors. It is important to isolate some of these possible factors and determine their relationships with the observed phenomenon. That is what this study intends to do. Given this state of affairs, the problem of this study, posed as a question is: How does funding influence effectiveness of secondary education in Cross River State, Nigeria?

\section{Purpose of the study}

This study is aimed at examining educational funding, utilization and effectiveness of education in Cross River State from 2006-2016. Specifically, the study seeks to find out;

1. How parent-teacher association (P T A) levies associate with effectiveness of secondary education in Cross River State.

2. How community contribution influence effectiveness of secondary education in Cross River State.

3. The qualitative output of Secondary education in Cross River State from 2006-2016?

\section{Research questions}

As a guide to this study, the following research questions are raised:

1. To what extent does P T A levies influence effectiveness of secondary education in Cross River State?

2. How does community contribution influence effectiveness of secondary education in Cross River State?

3. What is the qualitative output of Secondary education in Cross River State from 2006-2016?

\section{Statement of Hypotheses}

The following hypotheses are formulated to guide this study:

1. P T A levies does not significantly influence the effectiveness of secondary education in Cross River State.

2. Community contribution does not significantly influence the effectiveness of secondary education in Cross River State. 


\section{Method}

The study area was Cross River State, Nigeria. The design for the study wasEx-post facto. It was used because the phenomena of interest had already taken place or occurred and cannot be manipulated in any way. The population of the study comprised 246 Secondary Schools in the three education zones of Cross River State and the entire population was sampled for the study because the number is small. However, the Principals were used to answer the research questions for the purpose of data generation.The instrument used for this study was a questionnaire titled "Secondary education funding effectiveness appraisal inventory" (SEFEAI)and checklists known as state budgetary allocation trend (SBAT) were used to elicit information from the respondents. The questionnaire was validated by two experts in Measurement and Evaluation. The reliability value ranging between 0.70 and 0.95 was established using Cronbach alpha method.Each item had four response options of Highly Provided (HP), Moderately Provided (MP), Rarely Provided (RP) and Not Provided (NP). The respondents were required to tick one of the options against an item to indicate the extent of funding.The statistical tool used for data analysis was two way analysis of variance and descriptive statistics.

\section{Results}

Table 1: Parent Teachers Association levies influence on the effectiveness of secondary education in Cross River State

Descriptive statistics for the influence of PTA levies on effectiveness of Secondary Schools

\begin{tabular}{|c|c|c|c|c|c|}
\hline $\mathrm{S} / \mathrm{N}$ & Year & PTA Levies & $\mathrm{N}$ & $\mathrm{X}$ & SD \\
\hline 1 & 2006 & $\begin{array}{l}\text { Low } \\
\text { Moderate } \\
\text { High } \\
\text { Total } \\
\end{array}$ & $\begin{array}{l}114 \\
95 \\
37 \\
246 \\
\end{array}$ & $\begin{array}{l}31.82 \\
33.72 \\
39.97 \\
33.78 \\
\end{array}$ & $\begin{array}{l}22.699 \\
31.173 \\
25.345 \\
26.691 \\
\end{array}$ \\
\hline 2 & 2007 & $\begin{array}{l}\text { Low } \\
\text { Moderate } \\
\text { High } \\
\text { Total }\end{array}$ & $\begin{array}{l}114 \\
95 \\
37 \\
246\end{array}$ & $\begin{array}{l}29.28 \\
22.72 \\
37.32 \\
27.96 \\
\end{array}$ & $\begin{array}{l}20.687 \\
23.126 \\
21.695 \\
22.281 \\
\end{array}$ \\
\hline 3 & 2008 & $\begin{array}{l}\text { Low } \\
\text { Moderate } \\
\text { High } \\
\text { Total }\end{array}$ & $\begin{array}{l}114 \\
95 \\
37 \\
246 \\
\end{array}$ & $\begin{array}{l}29.13 \\
33.91 \\
50.97 \\
34.26 \\
\end{array}$ & $\begin{array}{l}20.168 \\
30.521 \\
18.955 \\
25.540 \\
\end{array}$ \\
\hline 4 & 2009 & $\begin{array}{l}\text { Low } \\
\text { Moderate } \\
\text { High } \\
\text { Total }\end{array}$ & $\begin{array}{l}114 \\
95 \\
37 \\
246 \\
\end{array}$ & $\begin{array}{l}25.99 \\
26.64 \\
43.61 \\
28.87 \\
\end{array}$ & $\begin{array}{l}20.632 \\
20.767 \\
16.861 \\
21.025 \\
\end{array}$ \\
\hline 5 & 2010 & $\begin{array}{l}\text { Low } \\
\text { Moderate } \\
\text { High } \\
\text { Total }\end{array}$ & $\begin{array}{l}114 \\
95 \\
37 \\
246 \\
\end{array}$ & $\begin{array}{l}31.82 \\
28.51 \\
47.92 \\
32.96 \\
\end{array}$ & $\begin{array}{l}21.066 \\
22.783 \\
18.446 \\
22.270 \\
\end{array}$ \\
\hline 6 & 2011 & $\begin{array}{l}\text { Low } \\
\text { Moderate } \\
\text { High } \\
\text { Total }\end{array}$ & $\begin{array}{l}114 \\
95 \\
37 \\
246\end{array}$ & $\begin{array}{l}27.85 \\
37.48 \\
47.68 \\
34.55 \\
\end{array}$ & $\begin{array}{l}23.924 \\
29.315 \\
23.762 \\
26.961\end{array}$ \\
\hline 7 & 2012 & $\begin{array}{l}\text { Low } \\
\text { Moderate } \\
\text { High } \\
\text { Total } \\
\end{array}$ & $\begin{array}{l}114 \\
95 \\
37 \\
246 \\
\end{array}$ & $\begin{array}{l}37.01 \\
41.93 \\
64.68 \\
43.07 \\
\end{array}$ & $\begin{array}{l}26.337 \\
31.135 \\
23.928 \\
29.961 \\
\end{array}$ \\
\hline 8 & 2013 & $\begin{array}{l}\text { Low } \\
\text { Moderate } \\
\text { High } \\
\text { Total }\end{array}$ & $\begin{array}{l}114 \\
95 \\
37 \\
246 \\
\end{array}$ & $\begin{array}{l}31.66 \\
30.22 \\
60.70 \\
35.47 \\
\end{array}$ & $\begin{array}{l}23.592 \\
27.531 \\
19.714 \\
26.800\end{array}$ \\
\hline 9 & 2014 & $\begin{array}{l}\text { Low } \\
\text { Moderate } \\
\text { High } \\
\text { Total }\end{array}$ & $\begin{array}{l}114 \\
95 \\
37 \\
246 \\
\end{array}$ & $\begin{array}{l}25.40 \\
30.79 \\
39.27 \\
29.57 \\
\end{array}$ & $\begin{array}{l}20.841 \\
21.559 \\
21.812 \\
21.713 \\
\end{array}$ \\
\hline 10 & 2015 & $\begin{array}{l}\text { Low } \\
\text { Moderate } \\
\text { High } \\
\text { Total }\end{array}$ & $\begin{array}{l}114 \\
95 \\
37 \\
246 \\
\end{array}$ & $\begin{array}{l}35.04 \\
27.23 \\
47.95 \\
33.96 \\
\end{array}$ & $\begin{array}{l}25.924 \\
20.495 \\
25.903 \\
24.846 \\
\end{array}$ \\
\hline 11 & 2016 & $\begin{array}{l}\text { Low } \\
\text { Moderate } \\
\text { High } \\
\text { Total }\end{array}$ & $\begin{array}{l}114 \\
95 \\
37 \\
246 \\
\end{array}$ & $\begin{array}{l}36.69 \\
48.69 \\
54.62 \\
44.02 \\
\end{array}$ & $\begin{array}{l}28.546 \\
28.334 \\
22.490 \\
28.436\end{array}$ \\
\hline 12 & Overall Effectiveness & $\begin{array}{l}\text { Low } \\
\text { Moderate } \\
\text { High } \\
\text { Total }\end{array}$ & $\begin{array}{l}114 \\
95 \\
37 \\
246 \\
\end{array}$ & $\begin{array}{l}341.0088 \\
361.8316 \\
533.5135 \\
378.0041 \\
\end{array}$ & $\begin{array}{l}170.96191 \\
172.13433 \\
111.64667 \\
17626966\end{array}$ \\
\hline
\end{tabular}


Table 2:P T A levies does not significantly influence the effectiveness of secondary education in Cross River State.

Summary of Fishers' LSD for the influence of PTA levies on effectiveness of secondary schools

\begin{tabular}{|l|l|l|l|}
\hline Overall PTA levies & $\begin{array}{l}\text { Low } \\
(\mathrm{n}=114)\end{array}$ & $\begin{array}{l}\text { Moderate } \\
(\mathrm{n}=95)\end{array}$ & $\begin{array}{l}\text { High } \\
(\mathrm{n}=37)\end{array}$ \\
\hline Low & $341.01^{\mathrm{a}}$ & $20.82^{\mathrm{b}}$ & 192.50 \\
Moderate & $0.91 \mathrm{c}$ & 361.83 & 171.68 \\
High & $6.20^{*}$ & $5.40^{*}$ & 533.51 \\
$(\mathrm{MSW}=26900.171)$ & & \\
\hline
\end{tabular}

$* \mathrm{P}<.05$

(a) All group means are along the principal diagonal

(b)Differences among group means are above the principal diagonal

(c) T-values are below the principal diagonal

Table 3: How does community contribution influence effectiveness of secondary education in Cross River State?

Descriptive statistics for the influence of Community contribution on effectiveness of Secondary Schools

\begin{tabular}{|c|c|c|c|c|c|}
\hline $\mathrm{S} / \mathrm{N}$ & Year & Community contribution & $\mathrm{N}$ & $\mathrm{X}$ & SD \\
\hline 1 & 2006 & $\begin{array}{l}\text { Low } \\
\text { Moderate } \\
\text { High } \\
\text { Total }\end{array}$ & $\begin{array}{l}138 \\
66 \\
42 \\
246 \\
\end{array}$ & $\begin{array}{l}35.77 \\
27.02 \\
37.88 \\
33.78 \\
\end{array}$ & $\begin{array}{l}27.77 \\
23.25 \\
26.82 \\
26.69\end{array}$ \\
\hline 2 & 2007 & $\begin{array}{l}\text { Low } \\
\text { Moderate } \\
\text { High } \\
\text { Total } \\
\end{array}$ & $\begin{array}{l}138 \\
66 \\
42 \\
246 \\
\end{array}$ & $\begin{array}{l}30.37 \\
20.50 \\
31.74 \\
27.96 \\
\end{array}$ & $\begin{array}{l}21.67 \\
21.33 \\
23.52 \\
22.82 \\
\end{array}$ \\
\hline 3 & 2008 & $\begin{array}{l}\text { Low } \\
\text { Moderate } \\
\text { High } \\
\text { Total } \\
\end{array}$ & $\begin{array}{l}138 \\
66 \\
42 \\
246 \\
\end{array}$ & $\begin{array}{l}33.23 \\
33.67 \\
38.57 \\
34.26 \\
\end{array}$ & $\begin{array}{l}23.98 \\
28.50 \\
25.79 \\
25.54 \\
\end{array}$ \\
\hline 4 & 2009 & $\begin{array}{l}\text { Low } \\
\text { Moderate } \\
\text { High } \\
\text { Total }\end{array}$ & $\begin{array}{l}138 \\
66 \\
42 \\
246 \\
\end{array}$ & $\begin{array}{l}28.30 \\
26.76 \\
34.12 \\
28.87\end{array}$ & $\begin{array}{l}21.95 \\
16.89 \\
23.43 \\
21.03\end{array}$ \\
\hline 5 & 2010 & $\begin{array}{l}\text { Low } \\
\text { Moderate } \\
\text { High } \\
\text { Total } \\
\end{array}$ & $\begin{array}{l}138 \\
66 \\
42 \\
246 \\
\end{array}$ & $\begin{array}{l}34.16 \\
29.32 \\
34.74 \\
32.96 \\
\end{array}$ & $\begin{array}{l}23.75 \\
16.04 \\
25.33 \\
22.27 \\
\end{array}$ \\
\hline 6 & 2011 & $\begin{array}{l}\text { Low } \\
\text { Moderate } \\
\text { High } \\
\text { Total } \\
\end{array}$ & $\begin{array}{l}138 \\
66 \\
42 \\
246 \\
\end{array}$ & $\begin{array}{l}30.86 \\
37.14 \\
42.62 \\
34.55 \\
\end{array}$ & $\begin{array}{l}25.64 \\
27.82 \\
28.22 \\
26.96\end{array}$ \\
\hline 7 & 2012 & $\begin{array}{l}\text { Low } \\
\text { Moderate } \\
\text { High } \\
\text { Total }\end{array}$ & $\begin{array}{l}138 \\
66 \\
42 \\
246 \\
\end{array}$ & $\begin{array}{l}43.25 \\
39.73 \\
47.74 \\
43.07 \\
\end{array}$ & $\begin{array}{l}30.29 \\
28.98 \\
26.94 \\
29.40 \\
\end{array}$ \\
\hline 8 & 2013 & $\begin{array}{l}\text { Low } \\
\text { Moderate } \\
\text { High } \\
\text { Total } \\
\end{array}$ & \begin{tabular}{l|}
138 \\
66 \\
42 \\
246 \\
\end{tabular} & $\begin{array}{l}28.88 \\
45.12 \\
41.95 \\
35.47 \\
\end{array}$ & $\begin{array}{l}22.29 \\
31.48 \\
26.88 \\
26.80 \\
\end{array}$ \\
\hline 9 & 2014 & $\begin{array}{l}\text { Low } \\
\text { Moderate } \\
\text { High } \\
\text { Total } \\
\end{array}$ & \begin{tabular}{l|}
138 \\
66 \\
42 \\
246 \\
\end{tabular} & $\begin{array}{l}27.13 \\
30.44 \\
36.21 \\
29.57 \\
\end{array}$ & $\begin{array}{l}19.78 \\
24.36 \\
22.44 \\
21.71 \\
\end{array}$ \\
\hline 10 & 2015 & $\begin{array}{l}\text { Low } \\
\text { Moderate } \\
\text { High } \\
\text { Total }\end{array}$ & $\begin{array}{l}138 \\
66 \\
42 \\
246\end{array}$ & $\begin{array}{l}33.50 \\
27.42 \\
45.76 \\
33.96\end{array}$ & $\begin{array}{l}26.28 \\
17.83 \\
25.78 \\
24.85\end{array}$ \\
\hline 11 & 2016 & $\begin{array}{l}\text { Low } \\
\text { Moderate } \\
\text { High } \\
\text { Total }\end{array}$ & \begin{tabular}{l|}
138 \\
66 \\
42 \\
246 \\
\end{tabular} & $\begin{array}{l}41.02 \\
43.53 \\
54.67 \\
44.02 \\
\end{array}$ & $\begin{array}{l}31.32 \\
22.07 \\
25.22 \\
28.44\end{array}$ \\
\hline 12 & Overall Effectiveness & $\begin{array}{l}\text { Low } \\
\text { Moderate } \\
\text { High } \\
\text { Total }\end{array}$ & \begin{tabular}{l|}
138 \\
66 \\
42 \\
246 \\
\end{tabular} & $\begin{array}{l}365.86 \\
360.64 \\
445.19 \\
378.00 \\
\end{array}$ & $\begin{array}{l}181.16 \\
121.09 \\
217.14 \\
176.27 \\
\end{array}$ \\
\hline
\end{tabular}




\section{Table 4: Community contribution does not significantly influence the effectiveness of secondary education in Cross River State.}

Summary of Fishers' LSD for the influence of community contribution on effectiveness of secondary schools

\begin{tabular}{|l|l|l|l|}
\hline Overall community contribution & $\begin{array}{l}\text { Low } \\
(\mathrm{n}=138)\end{array}$ & $\begin{array}{l}\text { Moderate } \\
(\mathrm{n}=66)\end{array}$ & $\begin{array}{l}\text { High } \\
(\mathrm{n}=42)\end{array}$ \\
\hline Low & $365.86^{\mathrm{a}}$ & $5.22^{\mathrm{b}}$ & 79.33 \\
Moderate & $0.20^{\mathrm{c}}$ & 360.64 & 84.55 \\
High & $2.58^{*}$ & $2.46^{*}$ & 445.19 \\
$(\mathrm{MSW}=(30380.873)$ & & & \\
\hline
\end{tabular}

$* \mathrm{P}<.05$

(a) All group means are along the principal diagonal

(b) Differences among group means are above the principal diagonal

(c) T-values are below the principal diagonal.

Table 5: Data summaries for effectiveness of secondary education (2006-2016)

\begin{tabular}{|l|l|l|l|l|}
\hline S/N & Year & N & X & SD \\
\hline 1 & 2006 & 246 & 33.78 & 26.69 \\
\hline 2 & 2007 & 246 & 27.96 & 22.28 \\
\hline 3 & 2008 & 246 & 34.26 & 25.54 \\
\hline 4 & 2009 & 246 & 28.87 & 21.02 \\
\hline 5 & 2010 & 246 & 32.96 & 22.27 \\
\hline 6 & 2011 & 246 & 34.55 & 26.96 \\
\hline 7 & 2012 & 246 & 43.07 & 29.40 \\
\hline 8 & 2013 & 246 & 35.47 & 26.80 \\
\hline 9 & 2014 & 246 & 29.57 & 21.71 \\
\hline 10 & 2015 & 246 & 33.96 & 24.85 \\
\hline 11 & 2016 & 246 & 44.02 & 28.44 \\
\hline 12 & Overall Effectiveness & 246 & 378.00 & 176.27 \\
\hline
\end{tabular}

\section{Discussion}

Results of analysis in Table 1 show that the calculated F-ratios of 6.367, 11.071, 11.315, 11.270, 9.021, 13.794, 22.828, 6.193, 19.158, 8.081 and 19.993 for 2007, 2008, 2009, 2010, 2011, 2012, 2013, 2014, 2015, 2016, and overall PTA levies were each greater than the critical F-ratio of 3.04 at .05 level of significance using 2 and 243 degrees of freedom. This means that, except for 2006, Parent teachers' Association levies significantly influence effectiveness of secondary schools. Based on the significance of the overall comparison, the null hypothesis was rejected. Results of analysis in Table 2 show pair-wise significant difference in the comparisons between Low versus High PTA levies $(t=6.20, p<.05)$, and moderate versus high indicating that, the significant influence of the result was because of group difference between low and high, and moderate versus high PTA levies. Results from the mean values in the Table show that, it was schools with high PTA levies $(X=533.00)$ that were more effective than their counterparts that had moderate $(X=361.83)$ and low $(X=341.01)$ PTA levies.

Based on the results, it was concluded that the higher the PTA levies, the more effective were the secondary schools during the period under study.The independent variable in this hypothesis is Community contribution (categorised into Low, Moderate and High Community contribution), while the dependent variable is effectiveness of secondary education. Categorisationof the independent variable was based on responses of the School Principals. Principals who scored one standard deviation below the mean (X-1SD) were considered as saying their institutions received low Community contribution. Those who scored one standard deviation above the mean $(\mathrm{X}+1 \mathrm{SD})$ were considered as saying their institutions received high Community contribution, while those who scored about the mean $(1 \mathrm{SD} \pm \mathrm{X})$ were considered as saying their institutions received moderate Community contribution. One-Way Analysis of Variance (ANOVA) statistical technique was used in testing the hypothesis. 
Results of analysis in Table 3 show that the calculated F-ratios of 3.048, 5.289, 3.548, 10.419, 7.414, 3.806, and 3.783 for 2006, 2007, 2011, 2013, 2015, 2016, and overall Community contribution were each greater than the critical F-ratio of 3.00 at .05 level of significance using 2 and 243 degrees of freedom. This means that, except for 2008, 2009, 2010, 2012 and 2014 Community contribution significantly influences effectiveness of secondary schools. Based on the significance of the overall comparison, the null hypothesis was rejected. Results from the mean values in the Table show that, it was schools with high community contribution $(X=445.19)$ that were more effective than their counterparts that had moderate $(X=360.64)$ and low $(X=365.86)$ community contribution. Based on the results, it was concluded that the higher the community contribution received, the more effective were the secondary schools during the period under study.

Supporting the results of this study is the study carried out by Emenalo and Camilus (2012) on appraisal of community involvement in secondary school's development in Okigwe education zone in Imo state, three research questions were raised to include, how communities ensure proper utilization of funds provided for the running of secondary schools? The population of the study was 158 principals and chairmen of board. Mean scores were used in answering the research questions. The finding showed that lunching and PTA levies are the major strategies communities use in raising fund for the schools.

In agreement with the above study, Bartle (3013) conducted a study on influence of parent teacher association on school administration and two research questions were posed. The study population was made up of 214 secondary schools in the study area. Census was used since the schools were few and it was found out that PTA contributes immensely to the physical facilities in the schools as well as in monitoring teachers' relationship with students. This agrees with the assertion of Eze 2002, Odo 2007 in Okenwa and Elechi (2015) that government alone appears unable to meet up with the financial demands of schools which make the participation of the community and PTA in the school funding impressive.

It must be noted that some communities raise funds, equip schools and hand over to the government but most times, do not monitor the utilization which results to misappropriation (Ibekwe, 2012). Adding to the above state, Onyerke, (2012) opined that it is pertinent to note that community and parents play a role in the provision for building and maintenance, transport to school, food, uniform and other learning materials which is usually significant at the basic level and cannot be qualified.

\section{Conclusion}

The findings of the study showed that parent teachers association and community contribution has a great deal of influence on the funding of secondary education in Cross River State. Based on the findings, schools with high income and support from PTA and community contribution performed better in the external examination because they were able to purchase learning materials that enhanced learning.

\section{Recommendations}

1. Schools should form strong parent teachers association to support the school in funding and overall supervision of school activities.

2. Host communities should be made to understand the importance of supporting school funding in their areas.

3. More resources and time should be invested in secondary education students for better grooming to ensure adequate preparation for external examinations to avoid recording high percentage failure.

\section{References}

Anyanwu, S.A, Iheanach, B. O. N \&Anorue, C. (2016). Forms of challenges of community participation in funding rural primary schools in Imo state. Nigerian Journal, 16(1), 214-223.

Bantle, M. (3013).Influence of parent teachers' association on student administration.Retrieved online fromwww.influlence/of/teacher/association/on/student/administration.Html

Bassey, U. U, Akuegwu, B. A. \&Udida, A. I. (2007). Non-governmental initiative for funding universities in Nigeria. In J. B. Babalola, G.O. Akpa, A. O. Ayeni\& S. O. Adedeji (Eds) Access, Equity and Quality Higher Education. NAEP publication.

Egruidu, C. (2014). December 24.Collapse of secondary education.The sun news available at unnews online .com $/$ new $/ ?=96829$

Emenalo, F. C. \& Camillus, I. (2013).appraisal of community involvement in secondaryschool's development in Okigwe education zone of Imo state.Mediterranean Journal of Social science, 4(7), 13-20. 
Federal Republic of Nigeria, (2014).National policy on Education. Lagos: NERDC.

Ibekwe, C. C. (2012). Extent of community participation in the development of secondary school in Okigwe Education Zone. An unpublished Master's Degree Thesis, Faculty of Education, Imo State University.

Jimonze, E. \&Paqueo, V. (1996). Do local contributions affect the efficiency of publicprimary schools? Economics of Education Review, 15(4),377-386. Retrieved online from sciencedirect.co m/science/article/abs/pii/sc272775796000295 on 02/06/2018.

Okon, T. A. (2017). Role performance and administrator's effectiveness in secondary schools

inCalabar South Local Government Area, Cross River State, Nigeria. A thesis work in the Department of Educational Administration and Planning, University of Calabar.

Okenwa, G. N. \&Elechi, C. N (2015).Polities of funding education and extent of community participation in the administration of public secondary schools in Enugu State, Nigeria.Nigerian journal of educational administration and planning, 15(3), 695-704.

Oweh, I. (2013). A case for better educational funding in Nigeria Daily Independent, January 28, 2013.

Oyeike, D. I. (2012). The eve of the $21^{\text {st }}$ century; Threshold education.Strategies for entry and sustainable development. Calabar: Rapid education publishers Ltd. 